\title{
Profitablity Analysis of Welcome Engineers
}

\author{
J Pavithra, K. Venkatraman, Rajesh .S
}

\begin{abstract}
A fundamental impediment of the customary budget report containing the asset report and the benefit and misfortune record is that they don't give all the data identified with the budgetary tasks of a firm. They give some incredibly helpful data to the degree that the monetary record reflects the money related position on a specific information as far as the structure of benefits, liabilities and proprietors' value, etc and the benefit and misfortune record demonstrates the after effects of activities during a specific timeframe as far as the incomes got and the expense in curried during the year the budget summaries give a perspective on the budgetary position the tasks of a firm. The focal point of budgetary position is on key figures in the fiscal reports and the huge relationship that exists between them the investigation of fiscal reports to acquire a superior comprehension of the inflexible stance's and execution, money related position is the procedure of choice, connection and assessment. A fiscal summary is an accumulation of information which is sensibly and reliably composed by bookkeeping standards a comprehension of some budgetary parts of a business firm. It might demonstrate a situation at a minute in time, as on account of a monetary record or may uncover a progression of exercises over a given timeframe as on account of a pay articulation.
\end{abstract}

\section{Keywords: Asset Report, Budgetary Task, Timeframe}

\section{INTRODUCTION}

Budget reports allude to such articulations which contains financialinformation about a venture. They report benefit and the budgetary position of the business toward the finish of bookkeeping period[1],[3],[5]. The group budget summary incorporates in any event two explanations which the bookkeeper plans toward the finish of a bookkeeping period. The two articulations are: -

\section{The Balance Sheet}

2. Profit And Loss Account

3. Financial proclamation give some amazingly helpful data to the degree that monetary record reflects the budgetary position on a specific date as far as the structure of benefits, liabilities and proprietor value, etc and the Profit And Loss record demonstrates the aftereffects of activities during a specific timeframe as far as the incomes acquire and thecost brought about during the year[2],[4],[6]

In this manner the fiscal summary gives a condensed perspective on budgetary positions.

Revised Manuscript Received on July 22, 2019.

Ms. J Pavithra, Department of MBA, Bharath Institute of Higher Education and Research, Chennai, India.

Email: pavithralect@yahoo.com

K. Venkatraman, Department of Civil Engineering, Bharath Institute of Higher Education and Research, Chennai, India.

Email: venkatraman.civil@bharathuniv.ac.in

Rajesh.S, Department of Civil Engineering, Bharath Institute of Higher Education and Research, Chennai, India. Email: rajeshskr06@gmail.com

\section{A. Meaning of Financial Analysis}

The main undertaking of money related examination is to choose the data applicable to the decision under thought to the absolute data contained in the financial articulation. The subsequent advance is to mastermind the data in a manner to feature critical relationship. The last advance is elucidation and reaching of induction and determinations. Budget summary is the procedure of determination, connection and assessment[7],[9],[11].

\section{B. Features of Financial Analysis}

- To present an intricate information contained in the budget report in straightforward and reasonable structure.

- To order the things contained in the fiscal report in helpful and discerning gatherings.

\section{Purpose Of Analysis Of Financial Statements}

- To know the winning limit or gainfulness.

- To know the dissolvability.

- To know the money related qualities.

- To know the ability of installment of intrigue and profits.

- To make near investigation with different firms.

- To know the pattern of business.

\section{Procedure Of Financial Statement Analysis}

The following procedure is adopted for the analysis and interpretation of financial statements:-

- The expert ought to familiarize himself with standards and proposed of bookkeeping. He should know the plans and arrangements of the administration with the goal that he might almost certainly see if these plans are appropriately executed or not.

- The degree of examination ought to be resolved with the goal that the circle of work might be chosen. On the off chance that the point is discover. Procuring limit of the endeavor then investigation of salary explanation will be embraced. Then again, in the event that monetary position is to be examined, at that point accounting report examination will be important.

- It will include the gathering comparable information under same heads. Separating of individual parts of proclamation as per nature. The information is diminished to a standard structure.

- A relationship is built up among budget summaries with the assistance of apparatuses and procedures of investigation, for example, proportions, patterns, regular size, support stream and so on 


\section{OBJECTIVES}

- To Discussed the Financial proportion estimation and investigation.

- To examine National Bank exchanging late years

- To measure gainfulness, liquidity and credit the board of National Bank

- To demonstrate the budgetary security examination comprises of (productivity and liquidity).

- To examine the monetary record and salary proclamation

- To utilizing budgetary proportion investigation (FRA strategy).

- And to know by and large Bank money related execution condition.

\section{RESEARCH METHODOLOGY}

\section{A. Research Design}

Research philosophy is logical and orderly quest for relevant data on a particular point. Research strategy is an approach to efficiently take care of the exploration issue. It is the calculated structure inside which the exploration is directed. It encourages the scientist to know the criteria which they can choose that specific strategy and methodology will be pertinent to certain issue and other won't[8],[10],[12].

Distinct research configuration is utilized as a structure or diagram for directing the exploration venture. It indicates the subtleties of the strategies essential for getting the data expected to structure and additionally solver search issues. A decent research configuration establishes the framework for leading the venture. A decent research configuration will guarantee that the examination task is directed adequately and effectively. Normally, an examination configuration includes the accompanying parts, or undertakings

\section{DATA ANALYSIS AND INTERPRETATION}

\section{A. Liquidity Ratios}

- Current Ratio

- Quick Ratio

- Fixed Assets Turnover Ratio

- Current Assets to Fixed Assets

Table - 1 Current Ratio

\begin{tabular}{|l|l|l|l|}
\hline \multicolumn{4}{|l|}{ Current Ratio } \\
\hline Year & Current Assets & Current Liabilities & Current Ratio \\
\hline $\mathbf{2 0 1 3}$ & 396.88 & 215.93 & 1.84 \\
\hline $\mathbf{2 0 1 4}$ & 352.25 & 166.23 & 2.12 \\
\hline $\mathbf{2 0 1 5}$ & 360.33 & 218.74 & 1.65 \\
\hline $\mathbf{2 0 1 6}$ & 379.18 & 211.98 & 1.79 \\
\hline $\mathbf{2 0 1 7}$ & 400.16 & 250.68 & 1.60 \\
\hline
\end{tabular}

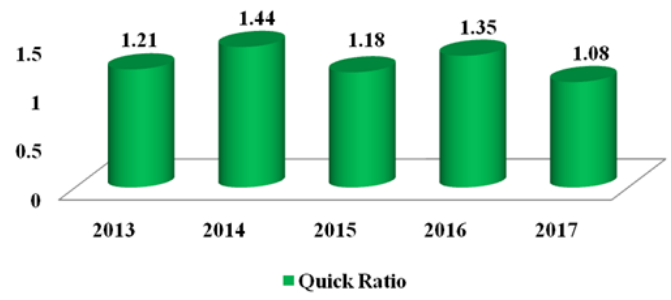

Figure - 2 Quick Ratio

Table -3 Fixed Asset Turnover Ratio

\begin{tabular}{|l|l|l|l|}
\hline \multicolumn{4}{|l}{ Fixed Assets Turnover Ratio } \\
\hline Year & Income from service & Net Fixed Assets & Ratio \\
\hline $\mathbf{2 0 1 3}$ & 787.67 & 234.82 & 3.35 \\
\hline $\mathbf{2 0 1 4}$ & 858.77 & 310.49 & 2.77 \\
\hline $\mathbf{2 0 1 5}$ & 671.92 & 303.80 & 2.21 \\
\hline $\mathbf{2 0 1 6}$ & 763.96 & 274.57 & 2.78 \\
\hline $\mathbf{2 0 1 7}$ & 881.60 & 263.72 & 3.34 \\
\hline
\end{tabular}

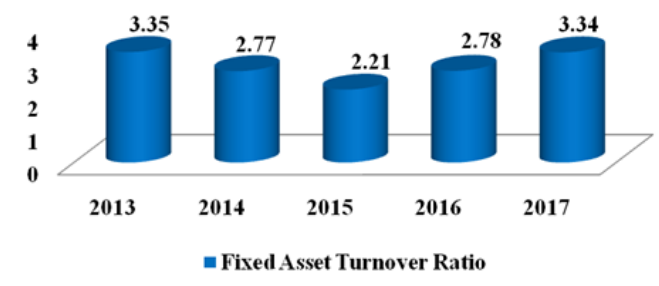

Figure - 3 Fixed Asset Turnover Ratio

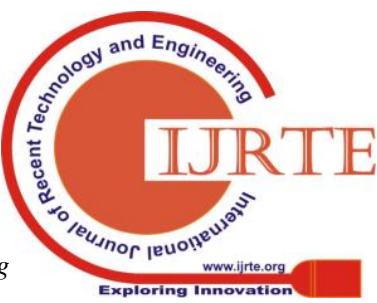


International Journal of Recent Technology and Engineering (IJRTE) ISSN: 2277-3878, Volume-8, Issue-2S8, August 2019

Table - 4 Current Assets to Fixed Asset Ratio

\begin{tabular}{|l|l|l|l|}
\hline \multicolumn{4}{|l|}{ Current Assets To Fixed Assets Ratio } \\
\hline Year & Current Assets & Fixed Assets & Ratio \\
\hline $\mathbf{2 0 1 3}$ & 396.88 & 234.82 & 1.69 \\
\hline $\mathbf{2 0 1 4}$ & 352.25 & 310.49 & 1.13 \\
\hline $\mathbf{2 0 1 5}$ & 360.33 & 303.80 & 1.19 \\
\hline $\mathbf{2 0 1 6}$ & 379.18 & 274.57 & 1.38 \\
\hline $\mathbf{2 0 1 7}$ & 400.16 & 263.72 & 1.52 \\
\hline
\end{tabular}

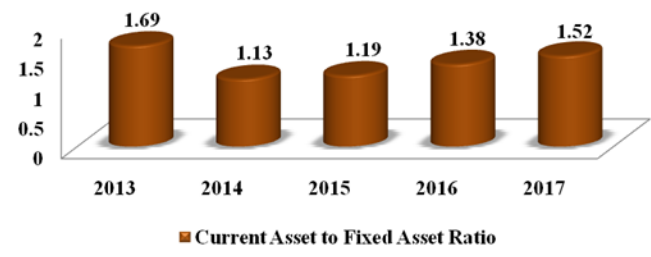

Figure - 4 Current Assets to Fixed Asset Ratio

Table - 5 Debt to Equity Ratio

\begin{tabular}{|l|l|l|l|}
\hline Year & Total Debt & Net worth & Debt to Equity Ratio \\
\hline $\mathbf{2 0 1 3}$ & 192.03 & 223.11 & 0.86 \\
\hline $\mathbf{2 0 1 4}$ & 256.59 & 239.52 & 1.07 \\
\hline $\mathbf{2 0 1 5}$ & 338.52 & 106.37 & 3.18 \\
\hline $\mathbf{2 0 1 6}$ & 324.21 & 117.31 & 2.76 \\
\hline $\mathbf{2 0 1 7}$ & 329.54 & 83.92 & 3.93 \\
\hline
\end{tabular}

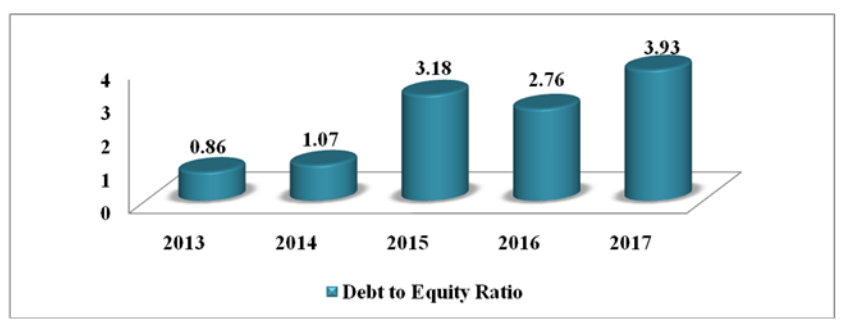

Figure -5 Debt to Equity Ratio

Table - 6Common-Size Balance Sheet Of Welcome Engineers For The Year 2014 And 2015

\begin{tabular}{|c|c|c|c|c|}
\hline Sources Of Funds & 2015 & Percentage & 2014 & Percentage \\
\hline Total Share Capital & 9.66 & 2.17 & 9.66 & 1.95 \\
\hline Employee Stock Option & 0.6 & 0.13 & 0.67 & 0.14 \\
\hline Reserves & 96.71 & 21.74 & 229.86 & 46.33 \\
\hline Detworth. & 106.37 & 23.91 & 239.52 & 48.28 \\
\hline Secured Loans & 308.74 & 69.40 & 198.67 & 40.05 \\
\hline Unsecured Loans & 29.78 & 6.69 & 57.92 & 11.67 \\
\hline Total Debt & 338.52 & 76.09 & 256.59 & 51.72 \\
\hline Total Liabilities & 444.89 & 100.00 & 496.11 & 100.00 \\
\hline Sources of Application & 2015 & \begin{tabular}{|l} 
Percentage \\
\end{tabular} & 2014 & Percentage \\
\hline Gross Block & 477.2 & 107.12 & 426.21 & 85.79 \\
\hline Less: Accum. Depreciation & 208.47 & 46.79 & 170.75 & 34.37 \\
\hline Net Block & 268.73 & 60.32 & 255.46 & 51.42 \\
\hline Cspital Work in Progress & 35.07 & 7.87 & 55.03 & 11.08 \\
\hline Investments & 0.05 & 0.01 & 0.07 & 0.01 \\
\hline Inventories & 102.7 & 23.05 & 112.58 & 22.66 \\
\hline Sundry Debtors & 186.84 & 41.94 & 179.55 & 36.14 \\
\hline Cash and Bank Balance & 7.38 & 1.66 & 8.4 & 1.69 \\
\hline Total Current Assets & 296.92 & 66.65 & 300.53 & 60.50 \\
\hline Loans and Advances & 62.7 & 14.07 & 51.69 & 10.41 \\
\hline Fixed Deposits & 0.71 & 0.16 & 0.03 & 0.01 \\
\hline Total CA, Lasns \& Advances & 360.33 & 80.88 & 352.25 & 70.91 \\
\hline Current Liabilities & 214 & 48.04 & 157.01 & 31.61 \\
\hline Provisions & 4.74 & 1.06 & 9.22 & 1.86 \\
\hline Total CL \& Provisions & 218.74 & 49.10 & 166.23 & 33.46 \\
\hline Net Current Assets & 141.59 & 31.78 & 186.02 & 37.45 \\
\hline Miscellaneous Excengeg & 0.06 & 0.01 & 0.2 & 0.04 \\
\hline Total Assets & 445.5 & 100.00 & 496.78 & 100.00 \\
\hline
\end{tabular}

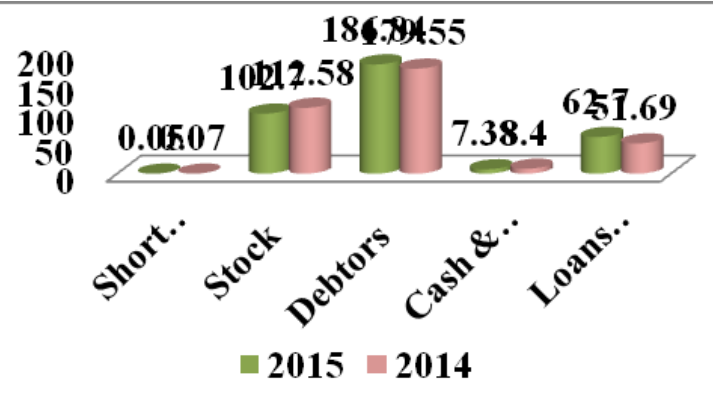

Figure - 6 Common-Size Balance Sheet Of Welcome Engineers For The Year 2014 And 2015

Table - 7 Common-Size Balance Sheet Of Welcome Engineers For The Year 2015 And 2016 
Profitablity Analysis of Welcome Engineers

\begin{tabular}{|c|c|c|c|c|}
\hline Sources Of Funds & 2016 & Percentage & 2015 & Percentage \\
\hline Equity Share Cspital & 9.66 & 2.18 & 9.66 & 2.17 \\
\hline Employes Stock Option & 0.52 & 0.11 & 0.6 & 0.13 \\
\hline Reserves & 107.65 & 24.38 & 96.71 & 21.73 \\
\hline Net worth & 117.31 & 26.56 & 106.37 & 23.90 \\
\hline Secured Loans & 308.8 & 69.94 & 308.74 & 69.39 \\
\hline Unsecured Loans & 15.41 & 3.49 & 29.78 & 6.69 \\
\hline Total Debt & 324.21 & 73.43 & 338.52 & 76.09 \\
\hline Total Liabilities & 441.52 & 100 & 444.89 & 100 \\
\hline Sources Of Application & 2016 & Percentage & 2015 & Percentage \\
\hline Gross Block & 481.12 & 108.84 & 477.2 & 107.11 \\
\hline Less: Acqum. Deprecistion & 236.87 & 53.58 & 208.47 & 46.79 \\
\hline Net Block & 244.25 & 55.25 & 268.73 & 60.32 \\
\hline Cappital Work in Progress & 30.32 & 6.85 & 35.07 & 7.87 \\
\hline Investments & 0.25 & 0.05 & 0.05 & 0.01 \\
\hline Inventories & 93.57 & 21.16 & 102.7 & 23.05 \\
\hline Sundry Debtors & 218.27 & 49.38 & 186.84 & 41.93 \\
\hline Cash and Bank Balance & 7.14 & 1.615 & 7.38 & 1.65 \\
\hline Total Current Assets & 318.98 & 72.16 & 296.92 & 66.64 \\
\hline Loans and Advances & 55.17 & 12.48 & 62.7 & 14.07 \\
\hline Fixed Deposits & 5.03 & 1.13 & 0.71 & 0.15 \\
\hline Total CA, Losns \& Advances & 379.18 & 85.78 & 360.33 & 80.88 \\
\hline Current Liabilities & 202.52 & 45.81 & 214 & 48.03 \\
\hline Provisions & 9.46 & 2.14 & 4.74 & 1.063 \\
\hline Total CL \& Provisions & 211.98 & 47.96 & 218.74 & 49.09 \\
\hline Net Current Assets & 167.2 & 37.83 & 141.59 & 31.78 \\
\hline Miscellangous Expenses & 0 & 0 & 0.06 & 0.013 \\
\hline Total Assets & 442.02 & 100 & 445.5 & 100 \\
\hline
\end{tabular}

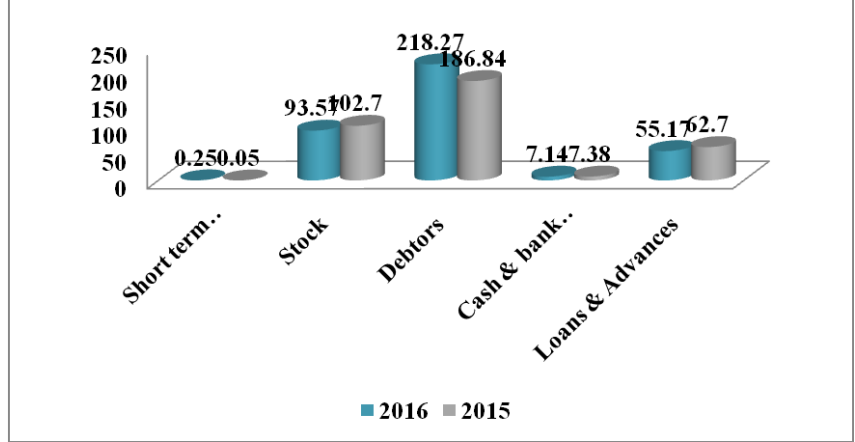

Figure - 7 Common-Size Balance Sheet Of Welcome Engineers For The Year 2015 And 2016

Table 8 - Common-Size Balance Sheet Of Welcome Engineers For The Year 2016 And 2017

\begin{tabular}{|c|c|c|c|c|}
\hline Sources Of Funds & 2017 & Percentage & 2016 & Percentage \\
\hline Total Share Capital & 9.71 & 2.35 & 9.66 & 2.19 \\
\hline Employee Stock Option & 0 & 0.00 & 0.52 & 0.12 \\
\hline Reserves & 74.21 & 17.95 & 107.65 & 24.38 \\
\hline Networth. & 83.92 & 20.30 & 117.31 & 26.57 \\
\hline Secured Loens & 304.73 & 73.70 & 308.8 & 69.94 \\
\hline Unsecured Loens & 24.81 & 6.00 & 15.41 & 3.49 \\
\hline Total Debt & 329.54 & 79.70 & 324.21 & 73.43 \\
\hline Total Liabilities & 413.46 & 100.00 & 441.52 & 100.00 \\
\hline Application Of Funds & 2017 & Percentage & 2016 & Percentage \\
\hline Gross Block & 521.9 & 126.23 & 481.12 & 108.85 \\
\hline Less: Accum. Depreciation & 273.48 & 66.15 & 236.87 & 53.59 \\
\hline Net Block & 248.42 & 60.08 & 244.25 & 55.26 \\
\hline Cspital Work in Progress & 15.3 & 3.70 & 30.32 & 6.86 \\
\hline Investments & 0.25 & 0.06 & 0.25 & 0.06 \\
\hline Inventories & 128.19 & 31.00 & 93.57 & 21.17 \\
\hline Sundry Debtors & 156.95 & 37.96 & 218.27 & 49.38 \\
\hline Cash and Bank Balance & 12.27 & 2.97 & 7.14 & 1.62 \\
\hline Total Current Assets & 297.41 & 71.93 & 318.98 & 72.16 \\
\hline Loans and Advances & 102.75 & 24.85 & 55.17 & 12.48 \\
\hline Fixed Deposits & 0 & 0.00 & 5.03 & 1.14 \\
\hline $\begin{array}{l}\text { Total CA, Loans \& } \\
\text { Advances }\end{array}$ & 400.16 & 96.79 & 379.18 & 85.78 \\
\hline Current Liabilities & 243.03 & 58.78 & 202.52 & 45.82 \\
\hline Provisions & 7.65 & 1.85 & 9.46 & 2.14 \\
\hline Total CL \& Provisions & 250.68 & 60.63 & 211.98 & 47.96 \\
\hline Net Current Assets & 149.48 & 36.15 & 167.2 & 37.83 \\
\hline Total Assets & 413.45 & 100.00 & 442.02 & 100.00 \\
\hline
\end{tabular}

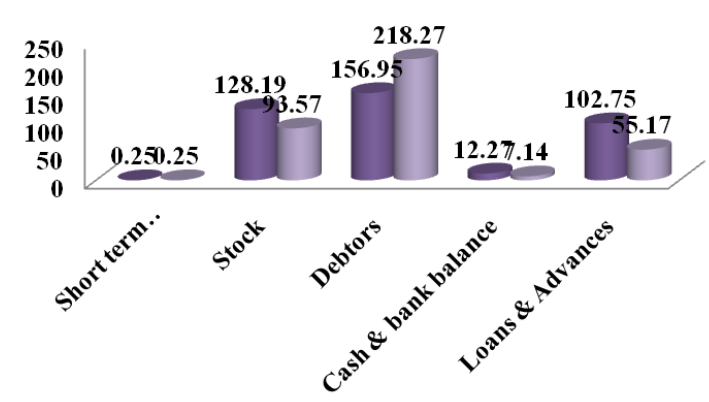

च2017 2016

Figure 8 - Common-Size Balance Sheet Of Welcome Engineers For The Year 2016 And 2017

Table 9 - Trend Analysis Of Selling And Admin Expenses

\begin{tabular}{|c|c|c|c|c|c|c|}
\hline $\begin{array}{l}\text { YEAR } \\
\text { Y }\end{array}$ & $\bar{x}$ & 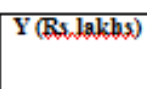 & $\mathrm{X}^{2}$ & $\begin{array}{l}\mathrm{XY} \\
\text { (Bs, lakbs, })\end{array}$ & $\begin{array}{l}\text { TREND } \\
\text { VALIE }\end{array}$ & DEVIATION \\
\hline 2013 & -2 & 83.10 & 4 & -166.2 & 81.124 & 1.98 \\
\hline 2014 & -1 & 87.67 & 1 & -87.67 & 79.513 & 8.16 \\
\hline 2015 & 0 & 65.86 & 0 & 0 & 77.902 & -12.04 \\
\hline 2016 & 1 & 68.00 & 1 & 68 & 76.291 & -8.29 \\
\hline 2017 & 2 & 84.88 & 4 & 169.76 & 74.68 & 10.20 \\
\hline TOTAL & & 389.51 & \begin{tabular}{|l|l|l|}
10 \\
\end{tabular} & -16.11 & & \\
\hline
\end{tabular}




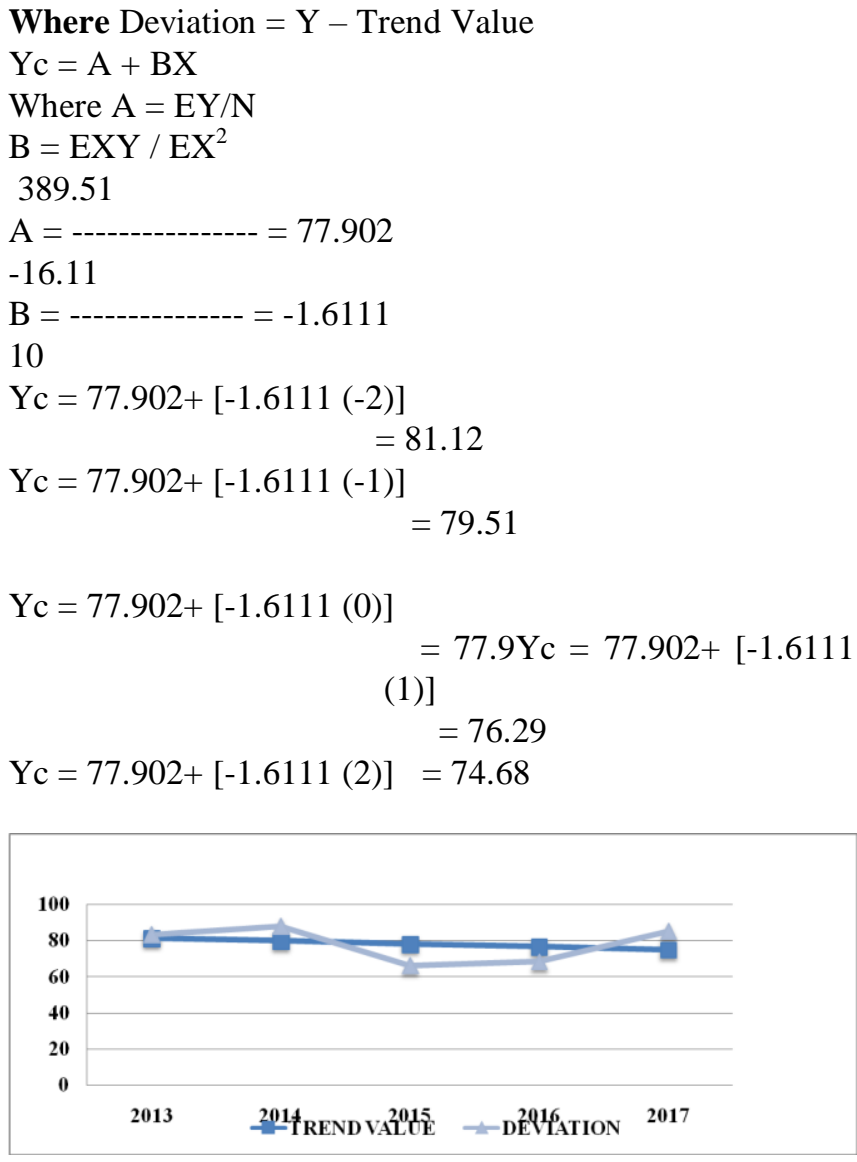

Table 9 - For the Forthcoming Years (2015 To 2017)

\begin{tabular}{|l|l|}
\hline YEAR & FUTURE TREND (Trend value + B) \\
\hline 2013 & 74.68 \\
\hline 2014 & 73.07 \\
\hline 2015 & 71.46 \\
\hline 2016 & 69.85 \\
\hline 2017 & 68.24 \\
\hline
\end{tabular}

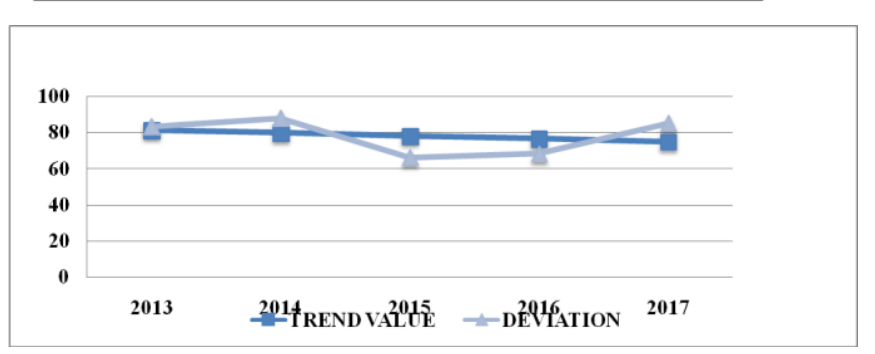

\section{RESULTS}

It can be seen that there is fluctuating pattern during the examination time frame. In the year 2014, it expanded to 2.12 from 1.84. It diminished to 1.65 in the year 2015 and it finds a slight ascent to 1.79 in the year 2016. In the year 2017 it again diminished to 1.60 . The administration should take medicinal measures to improve the present position

In the year 2014 it expanded to 1.44 from 1.21 of 2013. The above diagram it very well may be seen that there is fluctuating pattern during the investigation time frame. In the year 2016 it expanded to 1.35 and falls again to 1.08 in 2017.

It can be seen that there is fluctuating pattern during the examination time frame. In the year 2013 and 2014 it was in its pinnacle of 3.35 and 2.77 and falls profound to 2.21 in 2015 and there on it is expanded and recovered its underlying level

$>$ Current Assets expanded because of the expansion in the Sundry Debtors and the net fixed resources of the firm are diminished because of the charge of deterioration and there is no real addition in the fixed resources. The augmentation in current resources and the lessening in fixed resources came about on expanded in the proportion contrasted and the earlier year[13], [15],[17].

$>$ The obligation value proportion demonstrates a development from 0.86 in 2013 to 3.18 in 2015, in 2016 found a little decay and again rose to 3.93 . This demonstrates a negative sign and the organization ought to limit the buys of stock or fixed resources in future years.

$>$ The Debt to resources proportion was observed to be in a decent rate in 2013 and 2014 which is underneath half, yet there after in the fourth coming years, it expanded. This demonstrates a conceivable abuse of influence, and it might show potential issues meeting the obligation installments[14],[16], [18].

The obligation to value proportion is observed to be in a superior rate in the year 2013 yet abruptly falls steeply to 1.58 in 2014 and 0.18 in 2015. This was extremely an emergency period yet some way or another figured out how to increment to 2.76 and 1.46 in 2016 and 2017 individually. It's an unmistakable sign that the organization's money related hazard is expanding.

Operating proportion for the years 2013, 2014, 2015, 2016 and 2017 bit by bit diminished from 0.11 to 0.03

\section{DISCUSSIONS}

After the investigation of Financial Statements, the organization status is better, on the grounds that the Net working capital of the organization is multiplied from the most recent year's position[19],[21],[23].

$>$ The organization benefits are immense in the present year; it is smarter to announce the profit to partners.

$>$ The organization is using the fixed resources, which significantly help to the development of the association. The organization ought to keep up that impeccably.

$>$ The organization fixed stores are raised from the commencement, it gives the other salary i.e., Interest on fixed stores.

$>$ Steps must be taken to expand the present resource position of the firm in order to improve the liquidity position of the firm.

$>$ Percentage of obligation to value can be diminished to lessen the money related

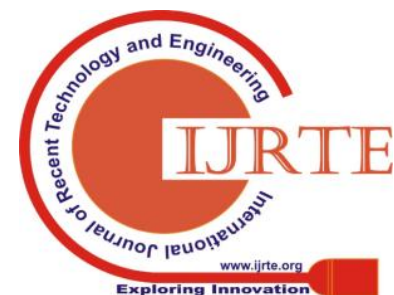


hazard[20],[22],[24].

$>$ Percentage of obligation in capital can be diminished in order to build the arrival to partners.

Steps can be taken to lessen the present obligation of the firm in order to have a stable money related position.

$>$ Steps can be taken to build the net benefit in order to expand the generally money related execution.

\section{CONCLUSION}

$>$ The organization's general position is at a decent position. Especially the present year's position is well because of raise in the benefit level from the most recent year position.

$>$ It is better for the association to enhance the assets to various areas in the present market situation[25],[27],[29].

$>$ Welcome Engineers is demonstrating changes in its benefit position from the previous 5 years, which is closed with the budget report investigation.

$>$ The earlier year resources were likewise expanded yet its working capital position was diminishing which says that the organization was not able meet its present liabilities[31],[33].

$>$ Preparation of budget summaries empowers the Government to see if the association is following different guidelines and guidelines or not. These announcements give a base to the guideline for the firm.

\section{REFERENCES}

1) BharthVajan R., Ramachandran S.,Psychographic dimensions of training,2016,International Journal of Pharmacy and Technology,V-8,I-4,P-23727-23729

2) Balakrishnan P., Bharthvajan R.,A study on human resource planning in hospitals in Chennai City,2014,International Journal of Applied Engineering Research,V-9,I-22,P-7503-7507

3) Priyadarsini P., Bharthvajan R.,Role of emotional intelligence training programme in reducing the stress of the nurses,2014,International Journal of Applied Engineering Research,V-9,I-22,P-7411-7421

4) Kerinab Beenu G., Bharthvajan R.,Empirical analysis on the cosmetic buying behavior of young women in South India,2014,International Journal of Applied Engineering Research,V-9,I-22,P-7361-7366

5) Balakrishnan P., Bharthvajan R.,Whistling in the wind,2014,International Journal of Applied Engineering Research,V-9,I-22,P-7586-7593

6) Krishnan B., Peter M.,Health hazards of Indian Bpo employee-an alarming issue,2014,International Journal of Applied Engineering Research,V-9,I-22,P-7336-7341

7) Kerinab Beenu G.H., Peter M.,Role of insurance in economic development,2014,International Journal of Applied Engineering Research,V-9,I-22,P-7532-7539

8) Balakrishnan P., Peter M., Priyadarsini P.,Efficiency of safety measures for wellbeing of employees in manufacturing industry,2014,International Journal of Applied Engineering Research,V-9,I-22,P-7376-7382

9) Anbarasi M., Praveen Kumar S.,Online sales promotions of herbal products and its effectiveness towards tanisha.com,2019,Indian Journal of Public Health Research and Development,V-10,I-1,P-195-200

10) Anbarasi M., Praveen Kumar S., Various online marketing and promotions strategies to improve the validation towards the organic products in the pharmaceutical sectors,2019,Indian Journal of Public Health Research and Development,V-10,I-1,P-263-269

11) Loganathan R., Praveen Kumar S.,Grievance handling a key factor for solving issues of employees in an organization,2014,International Journal of Applied Engineering Research,V-9,I-22,P-7483-7491

12) Loganathan R., Praveen Kumar S.,Study on preference of private label brands in super and Hypermarkets,2014,International Journal of Applied Engineering Research,V-9,I-22,P-7327-7335

13) Smitha M., Praveen Kumar S.,Understanding stress and its managementamong the nurses in Chennai city,2014,International Journal of Applied Engineering Research,V-9,I-22,P-7560-7565
14) Kerinab Beenu G.H., Praveen Kumar S.,A study on the investment behavior of Chennai investors in mutual fund schemes,2014,International Journal of Applied Engineering Research,V-9,I-22,P-7520-7525

15) Loganathan R., Praveen Kumar S.,Retention strategies key for organizational productivity,2014,International Journal of Applied Engineering Research,V-9,I-22,P-7443-7447

16) Pavithra J., Ganesan M., Brindha G.,State wise analysis of microfinance sector in India,2016,International Journal of Pharmacy and Technology,V-8,I-4,P-23417-23432

17) Pavithra J., Ganesan M.,A comparative study on microfinance in India and abroad,2016,International Journal of Applied Business and Economic Research,V-14,I-8,P-5471-5476

18) Pavithra J., Ganesan M.,A study on awareness and impact of micro-financial schemes,2016,International Journal of Applied Business and Economic Research,V-14,I-8,P-5449-5460

19) Senthilmurugan P., Pavithra J.,Consumer preference towards organised retailing with reference to Big Bazaar,2014, International Journal of Applied Engineering Research,V-9,I-22,P-7469-7475

20) Senthilmurugan P., Pavithra J.,Implication of social media marketing in growing healthcare industry,2014,International Journal of Applied Engineering Research,V-9,I-22,P-7448-7456

21) Loganathan R., Pavithra J.,Consumer perception towards private label brand over other brands in super markets and hypermarkets,2014,International Journal of Applied Engineering Research,V-9,I-22,P-7355-7360

22) Kerinab Beenu G., Pavithra J.,Tradeâ€"off between liquidity and profitability in logistics industry,2014,International Journal of Applied Engineering Research,V-9,I-22,P-7398-7401

23) Kerinab Beenu G., Pavithra J.,A study on the prospective consumerâ€ $€^{\mathrm{TM}_{S}}$ perception towards utility cars in Chennai city,2014,International Journal of Applied Engineering Research,V-9,I-22,P-7526-7531

24) Pavithra J., Dilli Babu P., Ambuli T.V.,A study on budgetary control at Maruti Service Masters, Chennai,2014,International Journal of Applied Business and Economic Research,V-12,I-2,P-151-161

25) Pavithra J., Dilli Babu P., Ambuli T.V.,A study on customer satisfaction of retro Garments Pvt Ltd, Chennai,2014,International Journal of Applied Business and Economic Research,V-12,I-2,P-381-391

26) Kerinab Beenu G.H., Pavithra J., Senthilmurugan P.,A study on the influence of promotional activities for TATA ARIA among consumers in Chennai,2014,International Journal of Applied Engineering Research,V-9,I-22,P-7572-7578

27) Vijayaragavan S.P.,An investigative expert that's general FBG sensors,International Journal of Mechanical Engineering and Technology,V-8,I-8,PP-1500-1505,Y-2017

28) Vijayaragavan S.P.,Equalization routing protocol for Wi-Fi sensor strategy,International Journal of Mechanical Engineering and Technology,V-8,I-8,PP-1662-1666,Y-2017

29) Karthik B., Kiran Kumar T.V.U., Vijayaragavan P., Bharath Kumaran E.,Design of a digital PLL using 0.35 $\hat{\mathrm{I}}^{1}$ /4m CMOS technology,Middle East Journal of Scientific Research,V-18,I-12,PP-1803-1806,Y-2013

30) Kanniga E., Selvaramarathnam K., Sundararajan M.,Kandigital bike operating system,Middle - East Journal of Scientific Research,V

31) Jasmin M., Vigneshwaran T., Beulah Hemalatha S.,Design of power aware on chip embedded memory based FSM encoding in FPGA,International Journal of Applied Engineering Research,V-10,I-2,PP-4487-4496,Y-2015

32) Jasmin M.,Optimization techniques for low power VLSI circuits,Middle East Journal of Scientific Research,V-20,I-9,PP-1082-1087,Y-2014

33) Jasmin M., Vigneswaran T.,Fuzzy controller for error control of on - Chip communication,2017 International Conference on Algorithms, Methodology, Models and Applications in Emerging Technologies, ICAMMAET 2017,V-2017-January,I-,PP-1-5,Y-2017 


\section{AUTHORS PROFILE}

Ms. J Pavithra Assistant Professor, Department of MBA, Bharath Institute of Higher Education and Research, Chennai, India.

K. Venkatraman Assistant Professor, Department of Civil Engineering, Bharath Institute of Higher Education and Research, Chennai, India.

Rajesh .S Assistant Professor, Department of Civil Engineering, Bharath Institute of Higher Education and Research, Chennai, India. 